Ann. Sci. For., 1987, 44 (2), 259-264

\title{
The route of the pollen tube from stigma to ovule in Populus nigra: a new look
}

\author{
M. VILLAR, M. GAGET * et C. DUMAS * \\ INRA, Station d'Amélioration des Arbres forestiers \\ Ardon, F 45160 Olivet \\ * Université Cl. Bernard Lyon I, RCAP, UM CNRS 380024 \\ F 69622 Villeurbanne Cedex
}

\begin{abstract}
Summary
The complete progress of the Populus nigra pollen tube from the stigma surface to the ovule micropyle of $P$. nigra has been examined recently by the classical ABF method and by a new scanning clectron microscope connected to a cryogenic preparation system.
\end{abstract}

Key words: Pollen, stigma, ovule, Populus.

\section{Introduction}

Hybridization programmes in Populus are limited by incompatibility barriers whose cellular sites and molecular mechanisms have not yet been defined. In spite of studies dealing with incompatibility in Populus in the last decade (WILling \& Pryor, 1976; STETTIFR \& AGER, 1984), reproduction events especially intra-pistillar phenomena have not been clarified yet. During an investigation of these events, we have examined the pollination pathway, especially the behaviour of the pollen tube from the stigma surface to the ovule. This work is part of a programme on interspecific incompatibility in Populus, involving both the INRA Station d'Amélioration, des Arbres forestiers (Orléans, France) and the Université de Lyon, Laboratoire de Reconnaissance cellulaire et d'Amélioration des Plantes (Villeurbanne. France) (Gaget et al., 1984 b).

\section{Materials and methods}

Branches of Populus nigra bearing flower buds were forced and flowers were matured in growth chambers (at the Université de Lyon, Villeurbanne, France). Before pollination, pollen viability was checked using the FCR test (Fluorochromatic Reaction) (Heslop-Harrison \& Heslop-Harrison, 1970). 
The progress of the pollen tube was monitored on the stigmatic surface and in the ovary cavity by scanning electron microscope (SEM), JEOL 35 CF connected to an EMSCOPE SP 2000 cryogenic system (of the Centre de Microscopie Electronique appliqué à la Biologie et la Géologie, Université de Lyon, Villeurbanne, France). The entire flower was fixed by rapid freezing, fractured and gold coated at $-160^{\circ} \mathrm{C}$ before observation. Pollen tubes were observed in the stylar tissue by the decolorized aniline blue fluorescence method $(\mathrm{ABF})$ in cleared whole mounts of pistil (Dumas \& KNOX, 1983).

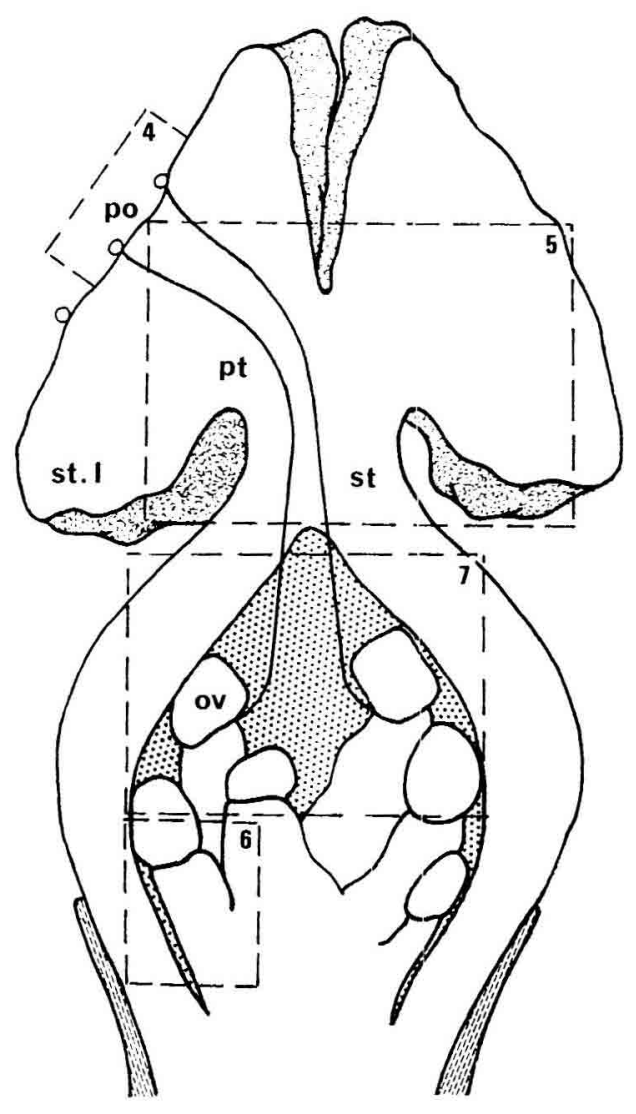

FIG. 1

Diagrammatic representation of a Populus nigra flower.

Représentation diagrammatique de la fleur de Populus nigra.

The areas 4 to 7 correspond to figures 4 to 7 of the plate. / Les rectangles 4 à 7 correspondent aux figures 4 à 7 de la planche photographique.

po : pollen grain / grain de pollen.

pt : pollen tube / tube pollinique.

st.1 : stigmatic lobes / lobes stigmatiques.

st : stylodium / stylode.

ov : ovule / ovule. 


\section{Results}

A Populus nigra catkin is composed of 30 to 40 flowers (fig. 2). A Populus nigra flower is represented in figure 1 and 3 : the bulbous ovary contains many ovules and is surmounted by four stigmatic lobes. Pollen grain adhesion, hydration and germination on a $P$. nigra stigmatic surface is observed in figure 4 . Pollen tubes penetrate the stigma, grow through the stigmatic lobes and join together within the funnel-shaped stylar neck (stylodium, fig. 5). Somes tubes enter the ovary cavity, and grow on the inner surface (fig. 6). They reach the ovules by the funiculus (fig. 6), or directly if the ovule makes contact with the inner ovary wall. After 25 hours $\left(20^{\circ} \mathrm{C}\right)$ the pollen tubes pass through the micropyle of the ovules (fig. 7).

\section{Discussion}

Sexual reproduction in Poplars has been mainly focused on the observation of pollinated stigma surfaces (HAMilton, 1976, SteTtler et al., 1980). The behaviour of pollen tubes in the pistillar tissue has rarely been described (GAGeT et al, 1984 a). In this paper we report the complete progress of the pollen tube from the stigma surface to the ovule micropyle for the first time for the genus Populus. The route of the pollen tube in the stigmatic tissue has been established by the classical ABF method. Complementary and original observations have been achieved in the ovary cavity by a scanning electron microscope, recently connected to a cryogenic preparation system. After rapid freezing, fresh pistil samples are fractured at low temperature before observation.

The visualization of the pollen tube progress in this cavity has raised the general problem of the guidance of the pollen tube to the micropyle of the ovule (see review by Heslop-Harrison \& Heslop-Harrison, 1985). A directional change in the pollen tube of $P$. nigra at the base of the funiculus strongly suggests that part of the ovule may be chemotropically active towards the pollen tube.

Moreover, these two physiological methods have enabled us to establish pollen tube growth rate in $P$. nigra pistils (VILLAR ef al., 1986), and to reveal the sites of pollen tube arrest in an incompatible cross (GAGET et al., 1984 a ; Villar, 1987). These modern investigations contribute to set the basic features of reproduction, and of male/ female interactions in Populus. 

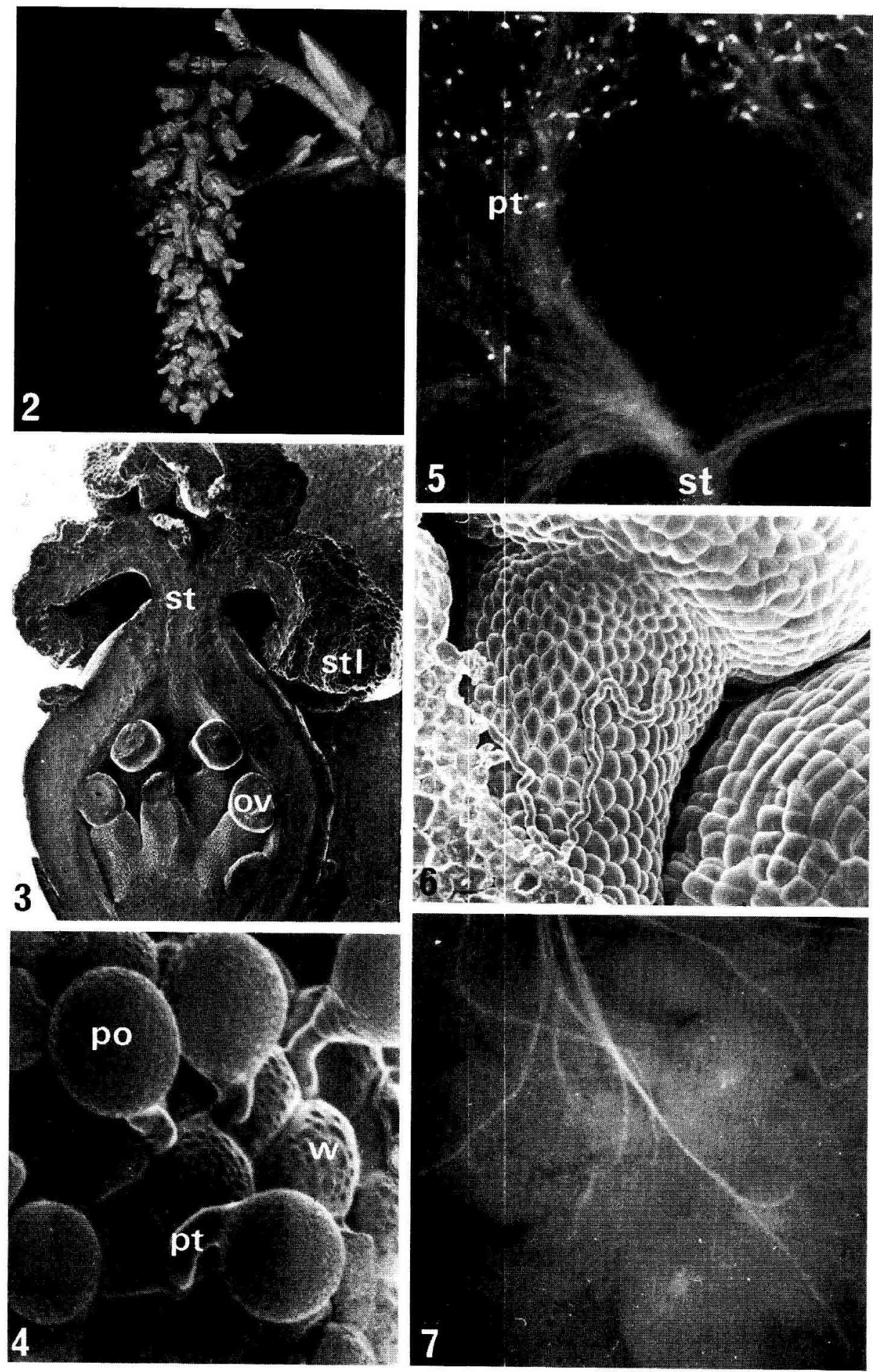
FIG. 2

Female catkin of Populus nigra $\times 1,5$.

Chaton florifère femelle de Populus nigra $\times 1,5$.

FIG. 3

Longitudinal section of a female flower of Populus nigra $(S E M) \times 50$.

Section longitudinale d'une fleur femelle de Populus nigra (Microcope électronique à balayage).

st.l : stigmatic lobes / lobes stigmatiques.

st : stylodium / stylode.

ov : ovule / ovule.

FIG. 4

Detail of the pollinated stigmatic surface of Populus nigra (SEM).

Détail de la surface stigmatique pollinisée de Populus nigra (MEB).

Pollen grains germinated and pollen tubes have penetrated the stigma surface / Les grains de pollen ont germé et les tubes polliniques ont pénétré la surface stigmatique.

po : pollen / grain de pollen.

pt : pollen tube / tube pollinique.

w : waxes / cires.

FIG. 5

Fluorescent micrograph of stigmatic lobes of Populus nigra ( $A B F$ method).

Faisceaux de tubes polliniques dans les lobes stigmatiques

se rejoignant au niveau du stylode (méthode $A B F) \times 150$.

Pollen grains have germinated (top of picture) and tubes can be seen traversing the stigmatic tissue towards the stylodium (base of picture) $\times 150$.

pt : pollen tube / tube pollinique.

st : stylodium / stylode.

Fig. 6

Pollen tube growing on the funiculus of the ovule.

Tube pollinique en croissance le long du funicule de l'ovule.

Note the change in direction towards the ovule (SEM + EMSCOPE) $\times 440 / A$ la base $d u$ funicule, le tube pollinique présente une brusque modification d'orientation en direction de l'ovule $(M E B) \times 440$.

FIG. 7

Fluorescent micrograph of the ovary cavity of Populus nigra (ABF method).

Tubes polliniques dans la cavité ovarienne.

Pollen tubes tips have reached the ovules $(25 \mathrm{~h}$ after pollination) $\times 70 /$ Leur extrémité se localise au niveau des ovules (méthode $A B F, 25$ h après pollinisation) $\times 70$. 


\section{Résumé \\ Cheminement du tube pollinique de $\mathrm{P}$. nigra du stigmate à l'ovule}

Nous avons examiné les principales étapes de la reproduction sexuée chez le Peuplier noir (Populus nigra). Cette étude présente le cheminement du tube pollinique de $P$. nigra depuis la surface stigmatique jusquau micropyle ovulaire (fig. 1 et fig. 4 à 7 ). Sa progression a pu être observée par la technique classique de visualisation des tubes polliniques par le Bleu d'Aniline (méthode $\mathrm{ABF}$ ) (fig. 5 et 7). L'utilisation du microscope électronique à balayage couplé à un système cryogénique EMSCOPE SP 2000 a permis des observations complémentaires originales sur le devenir du tube pollinique après pénétration dans lá cavité ovarienne (fig. 6).

Mots clés : Pollen, stigmate, ovule, Populus.

\section{Références}

Dumas C., Knox R.B., 1983. Callose and determination of pistil viability and incompatibility. Theor. Appl. Genet., 67, 1-10.

Gaget M., Said C., Dumas C., Knox R.B., 1984 a. Pollen-Pistil interactions in interspecific crosses of Populus (Section Aigeiros \& Leuce): pollen adhesion, hydratation and callose responses. J. Cell Sci., 72, 173-184.

Gager M., Villak M., Dumas C., Lemoine M., Teissiler du Cros E., 1984 b. Poplar improvment: new strategies currently in progress in France. Proc. of the XVIJth Session of the international Poplar commission, Ottawa. Canada, 25-30.

Hamiton D., 1976. Intersectional incompatibility in Populus. PhD thesis, Australian National Univ. Canberra, Australia.

Heslop-HarRison J., HesLop-Harrison Y., 1970. Evaluation of pollen viability by enzymatically induced fluorescence, intracellular hydrolysis of fluorescein diacetate. Stain Technol., 45, 115120.

Heslop-Harrison J., Heslop-Harrison Y.. 1986. Pollen-tube chemotropism : fact or delusion? In : Biology of reproduction and cell motility in plants and animal. M. Cresti and R. Dallai (Eds). University of Siena, Italia, 169-174.

Stettler R.F., AGer A.A., 1984. Mentor effect in pollen interactions. In : Cellular Interactions. H.F. Linskens and J. Heslop-Harrison (Eds). Springer-Verlag Berlin, 609-623.

Stettler R.F., Koster R., Steenackers V., 1980. Interspecific crossability studies in Poplars. Theor. Appl. Genet., 58, 273-282.

Villar M., 1987. Incompatibilité interspécifique chez Populus: approches physiologique et biochimique. Diplôme de Doctorat, Université de Lyon, France.

Villar M., Gaget M., Dumas C., 1986. Sexual reprocluction biology in Populus : compatibility and incompatibility. In : Biotechnology and ecology of pollen. D.L. Mulcahy, G.B. Mulcahy and E. Ottaviano (Eds). Springer-Verlag, NY, 514-517.

Willing R.R., Pryor L.D., 1976. Interspecific hybridization in Poplars. Theor. Appl. Genet., 47, 141-151. 